\title{
Use of Positron Emission Tomography/Computed Tomography in Radiation Treatment Planning for Lung Cancer
}

\author{
Akciğer Kanserlerinde Radyoterapi Planlamada Pozitron Emisyon Tomografi/Bilgisayarlı \\ Tomografi Kullanımı
}

\author{
Kezban Berberoğ/u \\ Anadolu Medical Center, Clinic of Nuclear Medicine, Istanbul, Turkey
}

\begin{abstract}
Radiotherapy (RT) plays an important role in the treatment of lung cancer. Accurate diagnosis and staging are crucial in the delivery of RT with curative intent. Target miss can be prevented by accurate determination of tumor contours during RT planning. Currently, tumor contours are determined manually by computed tomography (CT) during RT planning. This method leads to differences in delineation of tumor volume between users. Given the change in RT tools and methods due to rapidly developing technology, it is now more significant to accurately delineate the tumor tissue. F18 fluorodeoxyglucose positron emission tomography/CT (F18 FDG PET/CT) has been established as an accurate method in correctly staging and detecting tumor dissemination in lung cancer. Since it provides both anatomic and biologic information, F18 FDG PET decreases interuser variability in tumor delineation. For instance, tumor volumes may be decreased as atelectasis and malignant tissue can be more accurately differentiated, as well as better evaluation of benign and malignant lymph nodes given the difference in FDG uptake. Using F18 FDG PET/CT, the radiation dose can be escalated without serious adverse effects in lung cancer. In this study, we evaluated the contribution of F18 FDG PET/CT for RT planning in lung cancer.
\end{abstract}

Keywords: F18 fluorodeoxyglucose positron emission tomography/computed tomography, radiotherapy planning, nonsmall cell lung cancer, small cell lung cancer

\section{Öz}

Akciğer kanserlerinin tedavisinde radyoterapi önemli rol oynar. Küratif radyoterapinin uygun biçimde verilebilmesi için doğru tanı ve evrelendirme yapııması şarttır. Radyoterapi planlamada tümör sınırlarının doğru biçimde belirlenmesi ile coğrafik kayıpların önüne geçilebilir. Günümüzde radyoterapi planlamada bilgisayarlı tomografi (BT) görüntüleri kullanılarak tümör sınırları manuel olarak belirlenmektedir. Bu yöntem, kullanıcılar arasında tümör volümlerinin belirlenmesinde farklııklara yol açmaktadır. Hızla gelişen teknoloji sayesinde radyoterapi cihazlarının ve yöntemlerinin değişmesi uygun tedavinin verilebilmesinde gerçek tümör dokusunun gösterilmesinin önemini arttırmıştır. F18 florodeoksiglukoz pozitron emisyon tomografi/BT'nin (F18 FDG PET/BT) akciğer kanserlerinde doğru evreleme ve tümör yayılımı tespit etmede güvenilir bir yöntem olduğu bildirilmiştir. F18 FDG PET anatomik bilgilere ilave olarak biyolojik bilgileri de sağladığından klinisyenler arasında farkılığı anlamlı biçimde azaltmaktadır. Örneğin tümör dokusunu atelektazik alandan ayırarak ve boyutları benign nedenlerle büyümüş lenf nodlarını belirleyerek tümör volümlerini azaltmakta veya boyutları küçük ancak FDG tutulumu gösteren metastatik lenf nodlarını göstererek doğru alanın ışınlamasına olanak sağlamaktadır. F18 FDG PET/BT ile akciğer kanserlerinde ciddi yan etkilere yol açmadan doz artırımı yapılabilir. Bu yazıda akciğer kanserlerinde radyoterapi planlamasının F18 FDG PET/BT ile yapıımasının katkısı değerlendirilmiştir. Anahtar Kelimeler: F18 florodeoksiglukoz pozitron emisyon tomografi/bilgisayarlı tomografi, radyoterapi planlama, küçük hücreli dışı akciğer kanseri, küçük hücreli akciğer kanseri

Address for Correspondence: Kezban Berberoğlu MD, Anadolu Medical Center, Clinic of Nuclear Medicine, İstanbul, Turkey Phone: +90 5325846256 E-mail: kezbanberberoglu@hotmail.com Received: 26.11.2015 Accepted: 01.02.2016 


\section{Introduction}

External beam radiotherapy (RT) plays an important role in the management of non-small cell lung cancer (NSCLC) and small cell lung cancer $(\operatorname{SCLC})(1,2)$. In the delivery of RT with curative intent, an optimum treatment plan will deliver a sufficiently high dose of radiation to achieve high tumor control while delivering the least possible dose to the smallest possible volume of critical normal tissues to reduce the side effects of RT. The introduced RT techniques such as three-dimensional conformal RT (3D-CRT), intensity modulated radiation therapy (IMRT) (3), and image-guided radiation therapy (IGRT) have improved the accuracy of radiation delivery, leading to improved loco-regional control with reduced morbidity by facilitating delivery of a higher radiation dose to the tumor while sparing more normal tissue $(4,5)$. Before a treatment decision is made, accurate diagnosis and staging are essential parts of the RT treatment plan. The staging and diagnosis of the disease also play a crucial role in the success of definitive RT. Thus, feasible systemic treatments are enabled instead of unnecessary local treatments in patients with distant metastasis owing to accurate staging. The effectiveness of radiation therapy for lung cancer definitive treatment is limited by the radio-sensitivity of surrounding normal structures, by the difficulty in delineating the extent of malignant tissue using conventional imaging techniques, and by the identification of distant metastatic disease. Accurate and precise target delineation is necessary in order to take full advantage of these modern RT techniques. In addition, surgical resection is the standard of care for stage I and II NSCLC; however, significant co-morbidities may preclude surgical resection in those who are not able to tolerate the procedure. There is emerging data on the potential of ablative RT, called the stereotactic body radiation therapy (SBRT), in an effort to reduce morbidity and achieve better local control in a select group of patients. Herein we review the potential role of positron emission tomography (PET) imaging as a prognostic indicator in treatment planning and in the assessment of response to SBRT. Accurate delineation of target volume and preservation of peripheral critical organs determine treatment success in not only IMRT/volumetric modulated arc therapy but also SBRT. Target volumes and treatment volumes in RT planning are primarily determined by structural imaging with $\mathrm{CT}$, contrast $\mathrm{CT}$ or MRI, which together with clinical judgment are used to estimate the likely extension of microscopic disease in each case and thereby define the clinical target volume (CTV). Currently computed tomography (CT) is still being used for the determination of tumor volume and to obtain electron density information that is necessary for organ dose calculation during treatment planning. In a clinical study where the tumor contour was drawn by radiation oncologists manually, there were inter-user differences between radiation oncologists in the determination of tumor volumes (6). Anatomic imaging methods can be insufficient for assessment of some tumors and lymph nodes, and it is observed that radiation field might not include the tumor despite radiation dose escalation (7). Feasibility studies have found that the use of F18 fluorodeoxyglucose-PET/CT (F18FDG) for planning three-dimensional conformal radiation therapy improves the standardization of volume delineation as compared to $\mathrm{CT}$ alone in several types of cancers that are well imaged on PET (8). FDG-PET/CT was formed by the fusion of $\mathrm{CT}$ that allows anatomic information, and FDG-PET that provides biological information. Thus, both anatomic and biologic information is acquired together. FDG-PET/CT significantly decreases the delineation differences between oncologists, and it provides proper staging by identifying tumor and lymph nodes and hence determines gross target volume (GTV) more accurately during RT planning process. In addition, it was shown that PET/CT increases the sensitivity and accuracy in determining nodal GTVs than those detected by CT alone. The contribution of FDG-PET/ $\mathrm{CT}$ to RT planning has been investigated in various cancer types (9). Currently, the widespread use of FDG-PET/CT allows RT planning by this method (10). Functional/biologic imaging by FDG-PET/CT changes RT planning due to several reasons. The most important ones are:

1. Detection of lesions that are not observed by CT and MR (identification of small lymph nodes and distant metastases),

2. Reduction of tumor volumes by determination of fields without tumor such as atelectasis,

3. Allowing dose heterogeneity within one target by determining biologic differences within the tumor,

4. Superior ability in assessing the tumor after chemo-RT and during treatment,

5. "Response modulated RT" planning based on changing target volumes during the course of treatment $(11,12)$.

\section{Radiotherapy Planning in Non-Small Cell Lung Cancer by Fluorodeoxyglucose Positron Emission Tomography/Computed Tomography}

Lung cancer is the leading cause of cancer mortality. Fiveyear life expectancy is $14 \%$ in patients diagnosed with lung cancer, and surgery is indicated in approximately $1 / 3^{\text {rd }}(13)$. Surgery is the primary treatment for patients with early-stage disease. However, RT plays a significant role in those who cannot be operated due to medical and technical reasons. Disease control can be achieved by delivering the maximum radiation dose to the tumor and decreasing the dose to peripheral tissues; in NSCLC, this can be achieved via novel RT techniques such as IMRT, IGRT, and SBRT. RT planning by $\mathrm{CT}$ is a standard approach. Planning is performed by using anatomic information obtained by CT. When PET is used, biologic data can be included in planning as well, which allows dose escalation to the GTVs. 


\section{Staging}

Staging is the most critical process in NSCLC, since both treatment strategy and prognosis are subject to change according to disease stage. FDG-PET/CT is more accurate than $\mathrm{CT}$ in showing mediastinal and distant metastases, and this imaging platform changes the treatment plan in approximately $1 / 3^{\text {rd }}$ of patients (14). The sensitivity of FDG-PET/CT in mediastinal staging is higher than CT due to increased metabolic uptake of lymph nodes in FDG-PET/ $\mathrm{CT}$ that were otherwise noted to be of normal size by $\mathrm{CT}$. FDG-PET/CT can differentiate a metabolic active tumor from atelectasis (15). In addition, RT target volume can also be determined by detecting necrotic regions in the tumor. Thus, maximum radiation can be applied to different regions within the tumor by adjusting the intra-target dose, while decreasing the radiation dose that peripheral tissues will receive. As a result, fibrosis and long-term side effects will decrease (16). Patients can be operated if there is no lymph node involvement (NO) or if there is only hilar lymph node involvement (N1) in NSCLC. SBRT provides good local control in non-operable patients with T1-2 tumor and without lymph node metastasis (NO) (80 Gray in 6-8 fractions; 30-60 Gy in 3-5 fractions) (17). For this reason, the highly accurate mediastinal staging provided by FDG$\mathrm{PET} / \mathrm{CT}$ is critical for early stage NSCLC patients who are candidates for SBRT. Li et al. (17) evaluated 200 patients by FDG-PET/CT before the operation in their multi-centered study. They compared PET and the histopathologic results of surgery specimens. The sensitivity rate (83\%) and negative predictive value (NPV) (91\%) of PET/CT were found to be very high for mediastinal lymph node staging. Treatment volumes change owing to the presence of non-enlarged lymph nodes with increased FDG uptake. Hellwig et al. (18) reported the sensitivity rate of CT and FDG-PET as 56\% and $83 \%$ for all stages, respectively. Enlarged nodal size on CT showed a sensitivity of PET of $90 \%$ while sensitivity was $70 \%$ in normal lymph node sizes on CT. Routine elective nodal radiation is not recommended due to the high NPV of FDG-PET/CT in detecting mediastinal lymph node metastasis (19). SBRT can be a treatment option for patients if mediastinal lymph node metastasis is not detected in FDG-PET study. Selective lymph node radiation, which refers to the irradiation of lymph nodes with increased FDG-PET uptake, is a reliable method that provides local control in lymph nodes with decreased target volumes $(16,20)$. Hwangbo et al. (21) found that mediastinal staging by FDG-PET/CT led to false positive results in approximately $30 \%$ of patients. Therefore, pathologic evaluation with mediastinoscopy or endoscopic ultrasound (EUS-FNAB) guided fine needle aspiration biopsy may be more suitable. The sensitivity of EUS-FNAB and that of FDG-PET/CT are similar in the detection of mediastinal metastasis (EUSFNAB: 97.9\%, FDG-PET: 96.3\%) in squamous cell carcinoma while EUS-FNAB has a higher sensitivity in adenocarcinoma patients (EUS-FNAB: 94.6\%, FDG-PET: 77.8\%) (21).
A dosimetric study of van Der Wel et al. (20) evaluating 21 patients with N2 and N3 NSCLC showed that using FDG-PET/ $C T$ in radiation treatment planning process the esophagus and the lungs could be kept in the low dose area while the tumor received a high dose. FDG-PET/CT is one of the most important methods for the detection of NSCLC patients who are candidates for definitive RT. FDG-PET/CT affects staging by detection of distant metastasis and locally advanced disease, thus improving the success rates of cancer treatment with curative intent such as RT and chemotherapy (22). In a prospective study by Mac Manus et al. (23) on 153 patients, FDG-PET/CT changed treatment plan in $30 \%$ of patients to palliative treatment who were initially planned for curativeintent RT by conventional staging. This alteration was due to the detection of distant metastasis and extensive intrathoracic disease in $20 \%$ and $10 \%$ of patients, respectively. Staging with PET predicts life expectancy more accurately than conventional staging in patients planned for curativeintent definitive RT. It allows prevention of unnecessary treatment for patients with a short life expectancy. The accuracy of staging with PET/CT in patients with NSCLC is higher and it allows radiation oncologists to treat the malignant tissue alone. In a prospective study including 105 NSCLC patients, the treatment strategy for $26 \%$ of the patients was changed from curative therapy to palliation after staging with FDG-PET, overall, the treatment plan was changed in $67 \%$ of the entire patient group (24). In another study including 153 NSCLC patients, it was observed that disease staging changed in 33\% of the patients and target volumes changed in $25 \%$ of the patients after use of FDG-PET (25). It was further shown that the use of FDGPET study for the detection of tumor volumes significantly decreased the differences in contouring between radiation oncologists. FDG also led to intra-observer changes, as the same oncologist contoured the same target differently when also using FDG PET (26).

\section{Definition of Volumes Delineated in Radiotherapy Planning}

The definitions related to tumor localization were described in International Commission on Radiation Units (ICRU) 29th, 50th, 62nd, 71st and 83rd reports in detail ICRU. In this study, the definition of target volumes was made by using these protocols (Figure 1).

Gross Tumor Volume GTV: The visible tumor volume that can be felt by hand and can be detected by methods such as CT or MR.

Clinical Target Volume: In various studies, it was shown that there were undetectable subclinical malignant cells around the gross tumor. Thus, it was considered that these areas should also be included in the treatment volume. The treatment volume is determined by the radiation oncologist based on the aim of treatment (cure versus palliation).

$\mathrm{CTV}=\mathrm{GTV}+$ subclinical disease area 
Planning Target Volume: Patient and machine factors are considered in the delineation of the planning target volume (PTV), which is a geometrical definition. Accurate selection of radiation areas and sizes in order to create the desired dose in CTV depends on the definition of PTV by considering error margins. PTV volume and shape are determined by the selected therapy techniques such as SBRT, tumor location and set-up errors that depend on the previously defined CTV. In addition, PTV is dependent on tumor location that can influence assessment with respiration or digestive organ movement such as peristalsis, as well as on patient set-up during treatment planning session and beam inaccuracies. The required confidence margins should be added to therapy plan to minimize these problems. Internal margins include physiological alterations in position, volume and shape of the tumor according to anatomical reference points (i.e. bladder and rectum become full differently in each treatment, respiration, intestine and heart movements). Set-up margin includes patient-specific clinical and instrument specific mechanical and dosimetric factors besides unavailability of the same position for the patient and radiation area according to coordinate systems of therapy instrument.

PTV $=C T V$ + internal margin (IM) + set-up margin (SM).

Internal Target Volume: This is defined both in ICRU 62 and ICRU 50, and includes respiration, digestion, heart and other organ movements in addition to CTV.

ITV=CTV+IM

Planning Organ at Risk Volume: Therapy planning and total dose should be also decided by considering radiation sensitivities of critical organs and early/late side effects. Side effects can manifest in the long-term in some organs

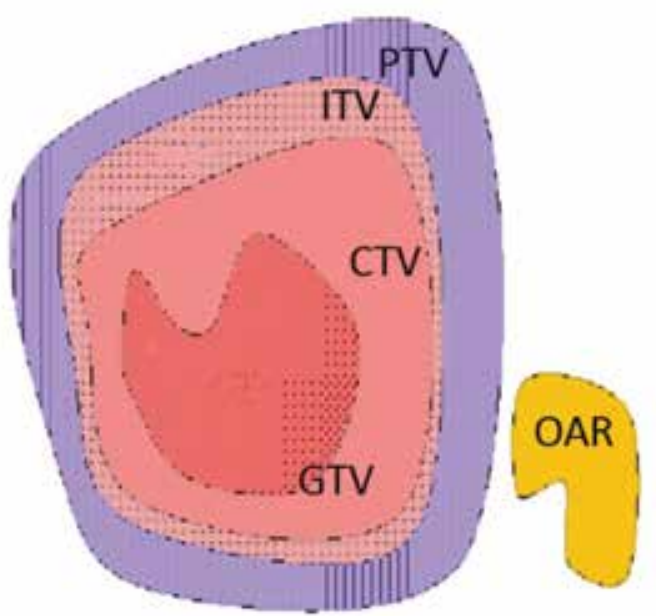

Figure 1. International Commission on Radiation Units 62: Treatment volume definitions

PTV: Planning target volume, CTV: Clinical target volume, GTV: Gross tumor volume such as the spinal cord, and permanent damage can occur with high doses. Early side effects such as mucositis and diarrhea may lead to interruption of therapy. Generally, the dose limits of specific tissues and organs that can be tolerated without side effects should be determined and these doses should not be exceeded. IM and SM should be added while determining "planning organ at risk volume" (PVR) that can affect the dose area and therapy planning significantly.

$P R V=O A R+I M+S M$

\section{Effect of Fluorodeoxyglucose Positron Emission Tomography on Target Volume Determination}

FDG-PET/CT leads to significant alterations in target volume size and shape as shown in various studies $(15,20,27,28,29,30,31,32,33)$.

In a recent review reported by Chi and Nguyen (34), it was observed that target volumes changed more than $20 \%$ while staging changed $20-50 \%$ as a result of treatment planning with FDG-PET. The most significant alteration was related to the differentiation of atelectasis from tumor tissue in PET images (Figure 2), and detection of lymph node metastases by observing increased FDG uptake in small-sized lymph nodes on CT $(15,27,28,29,30,33)$ (Figure 3). Bradley et al. (29) showed that there was a $58 \%$ change in the delineation of tumor volume when planned using FDG-PET/CT in stage I-III NSCLC patients along with a $31 \%$ change in disease stage. The ability to identify and differentiate atelectasis led to a decrease in GTV delineation in 3 out of 24 patients planned for 3D conformal RT, while the ability to identify small lymph node metastases via high FDG uptake led to a GTV increase in 10 patients as well as detecting additional parenchymal disease in one patient. Furthermore, the dosage to the normal lung and esophagus decreases with a small GTV by excluding atelectasis. Similar studies showed that doses to the heart, esophagus, spinal cord and normal lungs decreased due to alterations of the target volume when using FDG-PET/CT $(27,28,30,31,33)$. Although an increase in dose to peripheral tissue was observed in patients with greater GTV volume due to mediastinal lymph nodes detected by FDG-PET/CT, this increase was not found to be clinically significant in all patients. In a study of van Der Wel et al. (20), it was shown that nodal GTV decreased and thus, the dose that esophagus and normal received took decreased by FDG-PET/CT in N2-3 NSCLC patients. In a study performed in our clinic including 25 patients with lung cancer, a change was detected in $96 \%$ of the patients when target volumes were delineated by using F18 FDG-PET/CT versus CT alone. GTV and CTV volumes delineated by using FDG-PET/CT were lower than the volumes obtained by CT alone in $64 \%$ of the patients. This was due to PET/CT's enabling differentiation of the tumor from atelectasis in the lung (35). 


\section{Delineation of Target Volumes by Fluorodeoxyglucose Positron Emission Tomography}

Once PET and CT images are obtained and fused, tumor and target volume delineation are the most important steps to follow. Individual view assessment for each patient and determination of tumor contours are required because of the differences in bio-distribution, dynamic and screening features of screening agents used in nuclear medicine. Thus, a standard use and algorithm of
PET for the detection of target volumes is not available. Accurate and consistent detection of target volumes by PET is affected by certain factors. The first one is the limited spatial resolution of PET for the detection of GTV (it is approximately $4.5 \mathrm{~mm}$ in the latest generation PET/ CT scanners) and partial difficulty in the determination of lesions due to poor resolution. The small lesions can be detected if only they have high FDG uptake while almost all of the lesions larger than $1 \mathrm{~cm}$ or those with increased FDG uptake 4 times greater than background activity can
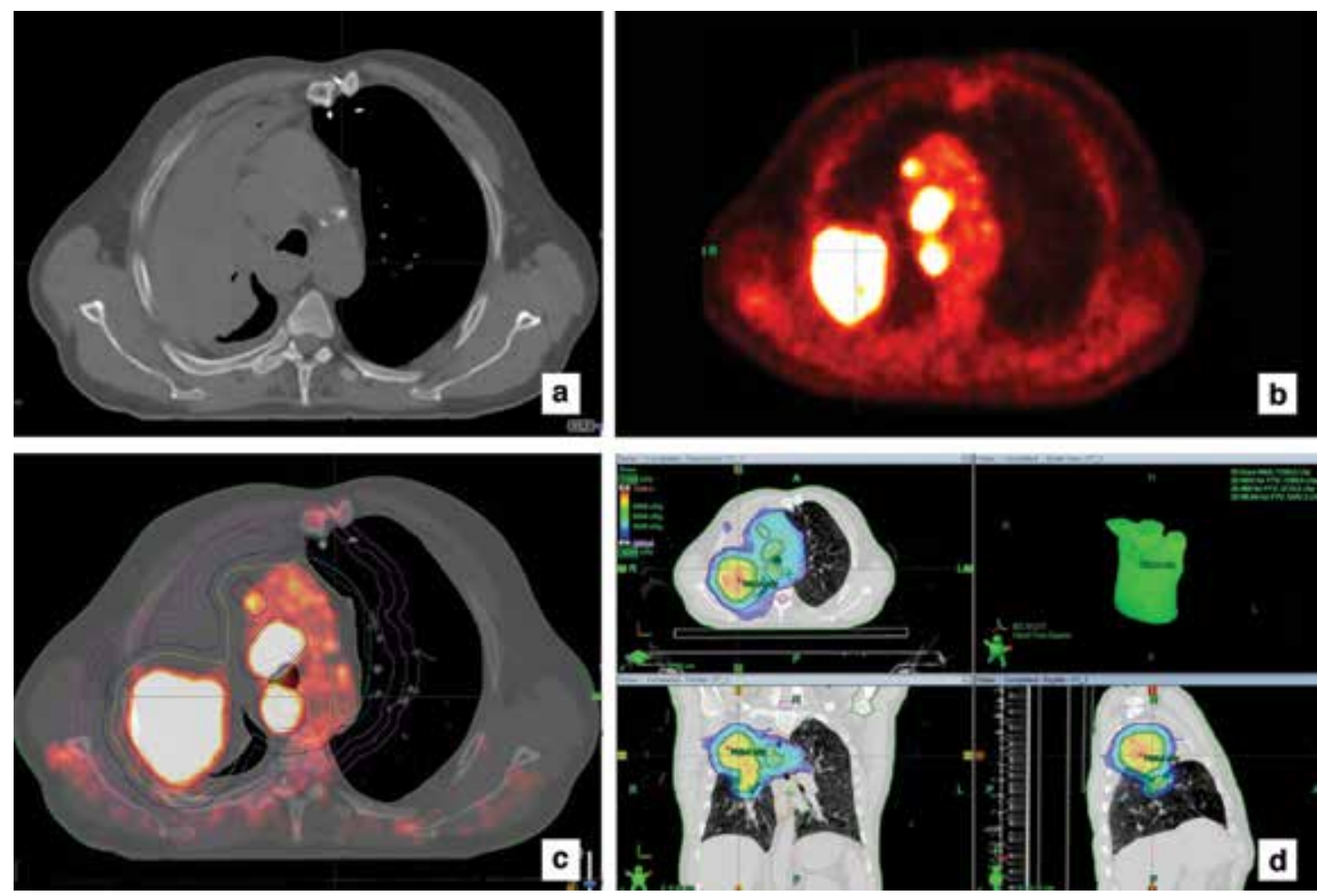

Figure 2. Non-small cell lung cancer, a) The atelectatic field cannot be separated from the tumor tissue in computed tomography, b) Positron emission tomography images showed increased fluorodeoxyglucose uptake in the tumor tissue, $\mathrm{c}$ and d) It was observed that there was a significant difference in target volumes formed by positron emission tomography/computed tomography fusion images
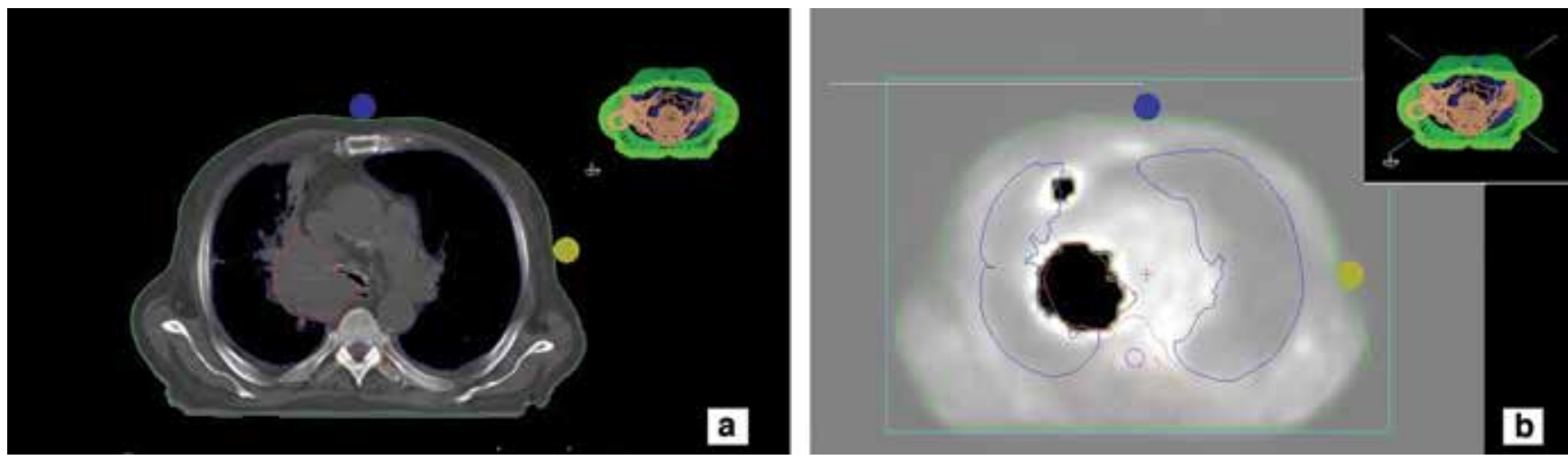

Figure 3. a) A normal-sized mediastinal lymph node in computed tomography images, b) Increased activity uptake was seen in positron emission tomography images, gross tumor volume included 
be detected. The detection of tumor contours by visual assessment is subjective, and hence proper delineation varies according to physician experience; certain lesions can be obscured due to partial poor spatial resolution. In addition, the proper assessment may be affected by view window selection, color scale, lesion/background ratio and high uptake in neighboring normal structures in PET images. These problems can be minimized by fusing PET and CT images. The tumor can be detected more clearly by obtaining more information with fused images of PET and CT imaging. PET images can also be used for RT planning in patients with FDG-PET staging and who are suitable for RT with curative intent (29). Ideally, PET staging images of RT candidates can be used directly in treatment planning if the views are acquired with the patient in the treatment position with suitable immobilization (36). If there is no PET/CT instrument in the department, PET and CT image fusion can be performed afterward, only if reference markers were used (37). If PET imaging are not acquired in the treatment position (i.e. if arms are not above the head) or if there has been a significant time lapse since staging PET images, then it is recommended that PET should be repeated in the accurate position. Target volumes can be delineated by visual assessment, experience and initiative of the physician as well as mathematical modeling methods using PET data obtained by semi-quantitative calculations in RT planning. Methods used for the detection of target volumes are as follows:

\section{Visual Assessment}

It is observed that standardized uptake value $\left(S U V_{\max }\right)$ and other similar parameters are being used in almost all studies in which RT planning is performed by visual assessment. Visual method is not defined in the literature, thus, it is recommended that a detailed protocol should be outlined by the centers that will use this method. Anatomic labels should confirm the suitability of PET/CT and fusion images, and the radiation oncologist and the nuclear medicine specialist should select the suitable diagnostic window before beginning the RT planning process by visual assessment. In a study by Doll et al. (38) including 44 international and different disciplines, it was shown that tumor volumes were determined most accurately in teams including nuclear medicine doctor and radiation oncologist.

\section{Automatic or Semi-Automatic Methods}

Methods that are more objective were investigated using automatic and semi-automatic methods in order to decrease the inter-user variability in the detection of target tumor volumes by FDG-PET/CT. However, these methods could not differentiate neoplastic tissue from physiologic and inflammatory processes since FDG is not a tumorspecific substance. Tumor volumes required revision in studies using real patient data while these methods yielded good results in studies using phantom data. It should be remembered that FDG is involved in macrophages and granulation tissue beside tumor cells. FDG-PET is a map showing three-dimensional glucose distribution, but it is not a map showing cancer cells (39).

\subsection{Standardized Uptake Value}

$S U V_{\text {max }}$ is the most compatible and reliable quantitative parameter commonly used for the assessment of tumor activity in clinical practice [SUV $V_{\text {max }}$ : Maximum activity concentration/(injected dose/weight)]. Eighty-seven patients with pulmonary nodules were included in the study. Lesions were confirmed by pathological assessment and followed up for at least 2 years. When the threshold value for SUV was considered as 2.5 for the diagnosis of lung cancer, the sensitivity, specificity and accuracy were $97 \%, 82 \%$, and $92 \%$, respectively (40). Therefore, SUV threshold value is recommended as 2.5 for the detection of GTV during RT planning (41).

\subsection{Thresholding Method}

In the most common thresholding approach, it is accepted that selection of the field with constant percent uptake levels according to maximum activity value of tumor helps to determine tumor contour (42). In the studies in which constant threshold value was accepted as $40-50 \%$, it was observed that this threshold value led to serious errors in lesion-size, homogeneity, and lesion/background contrastdepended volume calculations (43). This approach was shown to decrease GTV significantly in primary NSCLC patients who showed large, non-homogeneous activity uptake by comparing various contouring methods (44). Thus, more studies are required for the detection of gross tumor contours by contrast-dependent adaptive thresholding methods.

\subsection{Background Cut-off Method and Source/ Background Plan Algorithms}

In the background cut-off method, which is another automatic contouring method, tumor volumes are formed by drawing the field above the detected value (i.e. the fields showing 3 standard deviations from background activity for increase uptake level, fields above $2.5 \mathrm{SUV}$ ) (45). The advantage of this method is the detection of contours separately from heterogeneous FDG uptake in the lesion. However, the accuracy of this background cut-off approach depends on the accuracy of the statistical method used for this method. Contrast-oriented thresholding algorithm is obtained by calculating the effects of background FDG concentration on tumor volumes for the detection of GTV by PET in NSCLC patients (46). This approach showed that the GTV decreased as compared to the volumes obtained by $\mathrm{CT}$ alone, and it was compatible with pathologic tumor volume. This study detected a significant difference in pathologic tumor volume for tumors located in the lower lobes, as a result of breathing 
motion. It was predicted that these mistakes can be prevented by three-dimensional PET imaging. In a study, in which source/ background ratio determined by auto-segmentation approach was used, the results were compatible with pathologic tumor size in 33 NSCLC patients (47).

\subsection{Gradient-Based Approach}

PET-GTV detected by gradient-based approach is recommended in order to minimize statistical image noise and resolution blur (48). In a phantom study by WernerWasik et al. (49), gradient-based approach produced results that were more accurate as compared to other methods in terms of PET-GTV detection. In addition, this method was also compared with other methods in which GTV was determined by comparing to surgical samples $(50,51)$. A study including 10 patients who had undergone lobectomy for stage I-II NSCLC found that PET-GTV detected by 40$50 \%$ constant threshold and source/background ratio methods was better than GTV detected visually on CT images (50). In another study including 19 patients, tumor volumes detected by the gradient-based approach in PET/CT images obtained during normal breathing before surgery were highly compatible with surgical pathologic results (51).

\subsection{Automatic Methods}

Full-automatic thresholding methods were developed for the detection of tumor volumes by FDG-PET in lung cancer

Table 1. Methods of gross tumor volume delineation on positron emission tomography in correlation with surgical specimens

\begin{tabular}{|c|c|c|c|}
\hline 1.1.1.1.1.1 & $\begin{array}{l}\text { Patient } \\
\text { Number }\end{array}$ & Method of GTV delineation on PET & $\begin{array}{l}\text { Correlation between CT, PET, PET/CT and pathologic } \\
\text { tumor size }\end{array}$ \\
\hline \multirow[t]{3}{*}{ Lin et al. (46) } & 37 & Halo for tumor observed in fused PET/CT images & $\begin{array}{l}\text { Stronger correlation between GTV and pathologic tumor } \\
\text { dimensions were observed with PET/CT }\end{array}$ \\
\hline & & & Mean SUV of the external margin of halo was $2.41 \pm 0.73$ \\
\hline & & & $\begin{array}{l}\text { T stage and histology significantly influenced SUV at the } \\
\text { edge of halo }\end{array}$ \\
\hline Yu et al. (52) & 52 & SUV of 2.5 & $\begin{array}{l}\text { FDG-PET/CT had significantly better correlation with } \\
\text { surgical specimens than } \mathrm{CT} \text { or PET alone, especially in the } \\
\text { presence of atelectasis }\end{array}$ \\
\hline Yu et al. (53) & 15 & SUV threshold of $3.0 \pm 1.6$ & $\begin{array}{l}\text { Best correlation between PET GTV and actual tumor was } \\
\text { found at the SUV threshold of } 3.0 \pm 1.6\end{array}$ \\
\hline Wu et al. (54) & 31 & Thresholding with $20-55 \% \mathrm{SUV}_{\max }$ & $\begin{array}{l}\text { Maximal tumor dimension was more accurately predicted } \\
\text { by CT at the window-level of } 1.600 \text { and }-300 \mathrm{HU} \text { than } \mathrm{PET} \\
\mathrm{GTV} \text { (best correlation with pathologic tumor volume at } \\
50 \% \mathrm{SUV}_{\max } \text { ) }\end{array}$ \\
\hline $\begin{array}{l}\text { Schaefer et al. } \\
\text { (55) }\end{array}$ & 15 & $\begin{array}{l}\text { Tumor threshold }=A \text { * mean } \\
\text { SUV70\% }+B \text { *background }\end{array}$ & $\begin{array}{l}\text { Pathologic tumor volume: } 39 \pm 51 \mathrm{ml} \\
\text { PET tumor volume: } 48 \pm 62 \mathrm{ml} \\
\text { CT tumor volume: } 60.6 \pm 86.3 \mathrm{ml} \\
\text { Both CT and PET volumes were highly correlated with } \\
\text { pathological volumes }(p<0.001) \text {. } \\
\text { Increased variation between PET and pathological tumor } \\
\text { volumes were observed in lower lobes. }\end{array}$ \\
\hline $\begin{array}{l}\text { van Baardwijk } \\
\text { et al. (47) }\end{array}$ & 33 & Source-to-background ratio autosegmentation & $\begin{array}{l}\text { Maximal tumor diameter of the PET GTV was highly } \\
\text { correlated with that in surgical specimens (CC: } 0.90) \text {. } \\
\text { Auto-segmented GTVs were smaller than manually } \\
\text { contoured GTVs on PET/CT }\end{array}$ \\
\hline $\begin{array}{l}\text { Wanet et al. } \\
\text { (50) }\end{array}$ & 10 & $\begin{array}{l}\text { Gradient based method } \\
\text { Fixed theroshold at } 40 \text { and } 50 \% \text { of the SUV } \\
\text { Adaptive therosholding based on the source-to- } \\
\text { background ratio }\end{array}$ & $\begin{array}{l}\text { Comparison of both CT and PET/CT } \\
\text { Gradient-based method led to the best estimation of the } \\
\text { GTV } \\
\text { PET GTVs were smaller than CT GTVs in general }\end{array}$ \\
\hline $\begin{array}{l}\text { Cheebsumon } \\
\text { et al. (51) }\end{array}$ & 19 & $\begin{array}{l}\text { Absolute SUV cut-off }(2.5) \\
\text { Fixed threshold at } 50 \% \text { and } 70 \% \mathrm{SUV}_{\max } \\
\text { Adaptive thresholding } 41-70 \% \mathrm{SUV}_{\max } \\
\text { Contrast oriented algorithm } \\
\text { Source to background ratio } \\
\text { Gradient based method }\end{array}$ & $\begin{array}{l}\text { Adaptive } 50 \% \text { gradient- based methods generated the } \\
\text { most consistent maximal tumor dimension, which had a } \\
\text { fair correlation with pathological tumor size }\end{array}$ \\
\hline
\end{tabular}


patients. Automatic thresholding methods using source/ background algorithm is one of the most frequently used methods. If automatic contouring is performed using only functional images for RT planning, serious errors may occur. Primarily, it is important to match the images obtained by $\mathrm{CT}$ and the other anatomic imaging methods before determining tumor volume by automatic segmentation. Afterward, these should be revised by the planner since pathologic and physiologic distribution of the radioactive substance cannot be differentiated by automatic thresholding methods.

IA standardized automatic method for the delineation of GTV has not been established yet, although the methods discussed above have been reported for the detection of tumor volume. The concordance of real tumor volume obtained by surgery and different GTV detection methods in NSCLC patients are summarized in Table 1 (34).

\section{Tumor Movement: Radiotherapy Planning by Gated Positron Emission Tomography/Computed Tomography}

Organ movement and thus, tumor motion due to respiration, cardiac cycle, and other factors, is a significant issue in the delineation of the target tumor volume in thoracic malignancies. Calculations in RT planning should be performed by taking organ movements into consideration (56). A more accurate treatment can be delivered by following organ movement. If the tumor volume moves out of the contours, a part of the tumor can remain in the low-dose field due to organ motion. A few non-randomized studies described adverse effects related to average lung dose, despite the belief that high doses are advantageous for lung cancer patients (57). The peripheral healthy tissue can be preserved while increasing the dose to the tumor, and a smaller margin can be used to create the PTV by four-dimensional (4D) RT. PET, as well as CT images, can be recorded synchronized with the respiratory cycle in $4 \mathrm{D}$ Gated PET/CT imaging. Images are formed by taking a specific phase of 4D PET/CT respiration cycle as a reference point, and image of the tumor that moves with breathing can be obtained (58). Therefore, tumor contours can be delineated more accurately and normal tissues can be preserved better. 4D Gated PET/CT corrects for movementdepended motion blur and shows the functionally active field of the tumor that is mobilized with respiration more clearly. In a study by Lamb et al. (59), tumor volumes of 4 lesions in the lower lobes of 3 patients were delineated, calculated by both $4 \mathrm{D} C T$ and $4 \mathrm{D}$ Gated PET/CT, and were compared. In this study, GTVs obtained by 4D PET/CT were $30 \%$ smaller in volume than those obtained by $4 \mathrm{D} C \mathrm{CT}$. In the same study, the difference between the target tumor volumes obtained by 4D CT and normal PET images was deemed as minor. Gated PET allows more accurate GTV detection than 4D CT for SBRT planning, especially in tumors located in the lower lobes, which have more movement. 4D CT has a decreased accuracy of tumor motion assessment in lower lobe lesions, due to the proximity of the tumor to soft tissues such as the liver on the right and the spleen and stomach on the left. Tumor motion is the most significant obstacle to the planning of conformal RT. The treating system should be compatible with the differences due to tumor motion (real time monitoring) at all times (60) or the radiation dose should be delivered only at a specific phase of the respiratory cycle. As a result, the definition of threedimensional conformal RT is termed as a four-dimensional or gated radiation therapy.

\section{Clinical Results of Radiotherapy Planning Performed by Positron Emission Tomography/ Computed Tomography}

The literature indicates that FDG-PET/CT significantly decreases clinical tumor volumes in patients with large lymph nodes without FDG uptake and atelectasis due to its high diagnostic accuracy in NSCLC. FDG-PET/CT was also observed to have a prognostic value since the $S U V_{\max }$ value is reported to predict survival in primary NSCLC patients. In addition, the pre- and post-RT SUV $V_{\max }$ values were found to correlate with overall survival and diseasefree survival. High SUV max $_{\text {malues }}$ were associated with poor survival in primary lung tumors and with the presence of lymph node metastasis (61). High glucose uptake of the tumor is related to its high metastatic potential. Mac Manus et al. (62) investigated the role of FDG-PET in the assessment of response to RT. In this study, screening was performed by FDG-PET for 88 NSCLC patients before and after chemotherapy (on average 70 days after RT initiation, $60 \mathrm{~Gy}, 30$ fractions for 6 weeks). The complete metabolic response was obtained in $45 \%$ of the patients while a partial metabolic response was obtained in $36 \%$ of the patients by FDG-PET after treatment. The mean survival was 31 months and 11 months in the group with a complete metabolic response and in the group without response, respectively. One-year survival was determined as $93 \%$ and $47 \%$ in the group with complete response and without response, respectively. This study detected that the results were statistically significant despite confounders such as inflammation due to RT. There are significant differences in SUV $V_{\max }$ changes during RT between the group that showed metabolic response and the group with no response. Overall survival was higher in the group with a metabolic response. The decrease ratio in $S U V_{\max }$ value directly correlated with disease-free survival (63). FDG-PET/ CT plays an important role in the detection of recurrent disease. Metabolic evaluation by PET/CT in NSCLC has a high accuracy rate after treatment (78-98\%) (64). Investigations can be performed as early as 6 weeks post treatment due to pneumonia and inflammation that may occur after RT, but the recommended interval is frequently 3-6 months. 
Metabolic response assessment is an important parameter for the detection of local failure and survival. The detection of residual metabolic activity allows for the possibility of additional planning (Figure 4). In a study by Velasquez et al. (65), PET images were assessed before and after radical chemotherapy in 101 non-operated NSCLC patients. The overall survival was significantly decreased in the group showing residual metabolic uptake in the post-treatment PET study. There was an association between detection of residual increased metabolic uptake after RT in large tumors and tumors with high $S U V_{\max }$ value. The clinical results of stage II-III NSCLC patients whose disease volumes were identified by FDG-PET/CT and who were treated with RT were reported in two recent studies $(66,67)$. In a pilot study including 32 patients treated with RT, only one local failure and one local progression were detected (66). The recurrence was in a lymph node. When the treatment plans were revisited, it was observed that this lymph node was FDG positive but was not included in the treatment volume. In another study on 137 stage III NSCLC patients and PETpositive areas, local recurrence was reported as $14.6 \%$ and distant metastases as $16.8 \%$ (67). These findings showed that clinical results of patients with stage II and III disease whose RT were planned by PET were as good as of those planned by using CT (68). Furthermore, the dose to the primary lesion can be increased while preserving the normal tissue in locally advanced NSCLC by using PET. Therefore, local control can be increased as well as survival, as was suggested by Aupérin et al. (69) in a meta-analysis.

\section{Radiotherapy Planning by Fluorodeoxyglucose Positron Emission Tomography/Computed Tomography in Small Cell Lung Cancer Staging}

SCLC consists of approximately $20-25 \%$ of lung cancers. It is often diagnosed at an advanced stage with distant metastases and exhibits an aggressive clinical behavior (70). In spite of aggressive treatment, it carries a poor prognosis (9). Accurate staging in SCLC is the most important factor in determining the most appropriate method of treatment. It is difficult to determine disease spread and especially to assess the involvement of mediastinal lymph nodes. Fischer et al. (71) compared FDG-PET/CT as a staging tool with standardized staging modalities (CT and bone scintigraphy) in their prospective study including 29 SCLC patients. In this study, PET/CT changed the plan in five of 29 patients (17\%), and it was shown that this method increased the accuracy of tumor definition. In another study, $8.3-9.5 \%$ of patients were up-staged to advanced stages with the addition of FDG-PET/CT $(72,73)$. Arslan et al. (74) evaluated the accuracy of staging by FDG-PET/CT and $C T$, and its relation to overall survival. When compared to staging by $\mathrm{CT}$, staging by FDG-PET/CT up-staged nine of 25 patients(36\%), while down-staging two patients (8\%). In addition, a significant survival difference was predicted ( $p=0.019$ ) by using FDG-PET/CT in the staging process, but there was no difference in those in which CT had been used ( $p=0.055)$. These studies recommend the use of FDGPET/CT for initial staging in SCLC during limited stage.
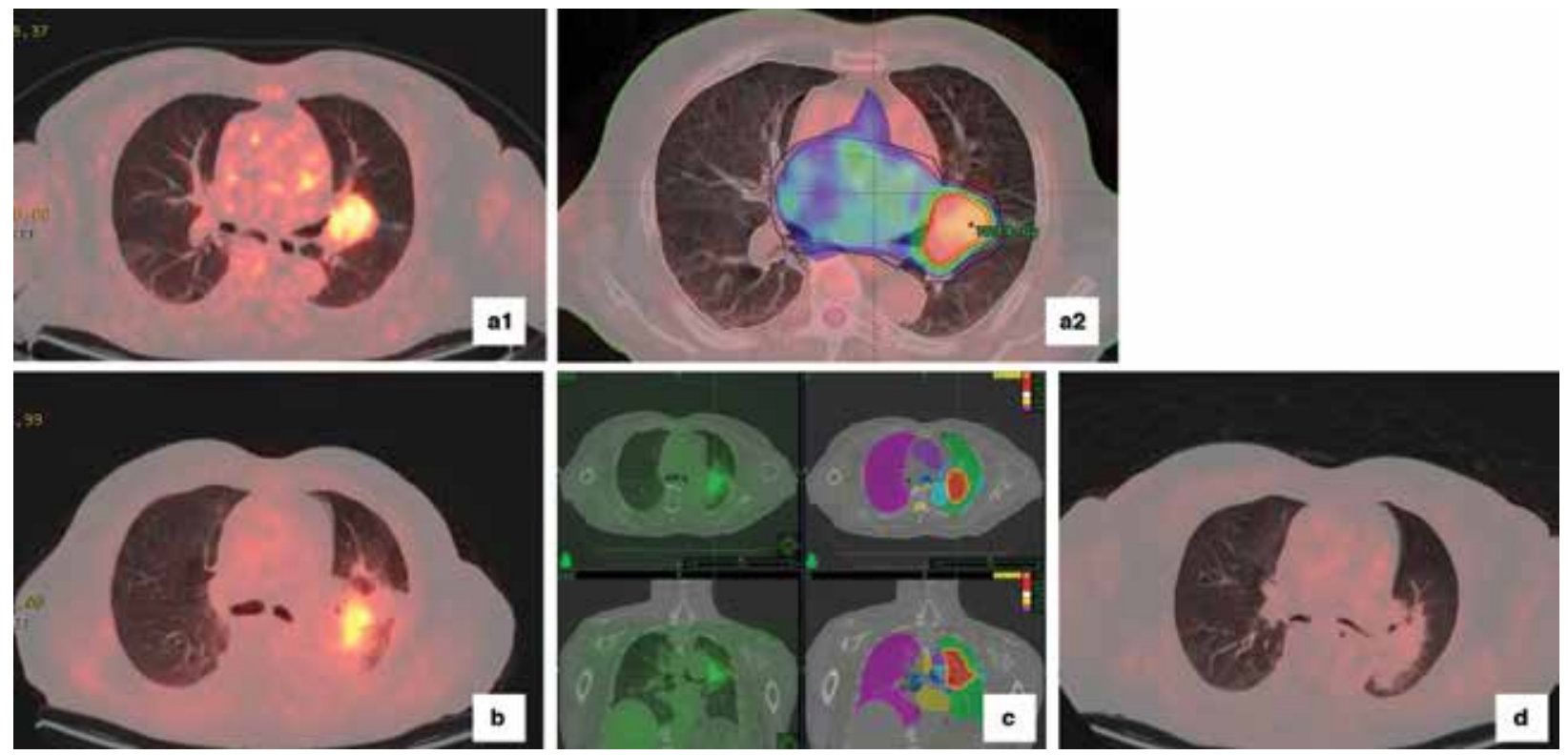

Figure 4. Non-small cell lung cancer, 82 y.o., M patient, a1) Abnormal increased metabolic activity was observed in the mass identified in the left parahilar region and, a2) Intensity modulated radiation therapy planning images by these views, b) Increased metabolic activity compatible with residual mass was seen in positron emission tomography/computed tomography that was applied for treatment-control after four months, c) Plan images belonged to stereotactic body radiation therapy that was applied to the residual mass, d) Pathologic activity was not observed in positron emission tomography/ computed tomography after one year (complete metabolic response) 


\section{Determination of Tumor Volumes by Fluorodeoxyglucose Positron Emission Tomography/Computed Tomography}

There are less studies in which tumor volumes were determined by FDG-PET/CT in SCLC patients when compared to NSCLC. Nevertheless, it can contribute to the treatment planning process by determining tumor volumes more accurately as in NSCLC.

\section{Radiotherapy Planning for the Field Involved Lymph Node with Fluorodeoxyglucose Positron Emission Tomography/Computed Tomography}

Elective nodal radiation of mediastinal lymph nodes in SCLC patients with limited disease decreases nodal failure rate. However, some physicians are reluctant to offer elective nodal radiation due to serious adverse effects as a result of large field of radiation. Baas et al. (75) evaluated involved field RT in early stage SCLC patients diagnosed by CT in their phase II study. Mean survival was 19.5 months with acceptable adverse effects. De Ruysscher et al. (76) investigated involved field RT in early stage SCLC patients diagnosed by CT in their phase II study. They assessed general survival and isolated lymph node failure rates, which was described as relapse in local lymph nodes out of target volumes in patients who had no failure identified in the treatment field. In this study, isolated lymph node metastases that were not included in the treatment field was found to be unexpectedly high (11\%). Involved field RT was considered as controversial by International Atomic Energy Agency (IAEA) when these findings were evaluated, and further prospective clinic studies were suggested (77). FDG-PET/CT can be used in order to determine the requirement of elective nodal radiation. Two recent studies assessed the requirement for elective nodal radiation after staging by FDG-PET/CT $(78,79)$. In a prospective study, van Loon et al. (78) assessed involved field RT by FDG-PET in 60 patients with limited stage SCLC disease. The mean overall survival was 19 months and isolated nodal failure rate was $3 \%$. The isolated nodal failure rate was significantly lower in the group planned by FDG-PET as compared to the group planned by CT (11\% vs. 3\%). Shirvani et al. (79) evaluated 60 patients with limited stage SCLC who were staged by FDG-PET and were treated with IMRT involved field RT. The 2-years survival rate was calculated as $58 \%$, and isolated nodal failure was detected in one patient $(3 \%)$. These studies concluded that involved field RT could be used reliably instead of elective nodal radiation in patients staged by F18 FDG-PET. In this way, the toxicity can be decreased or adjusted by not irradiating the PET negative lymph nodes. Involved field RT by FDG-PET in SCLC is a current discussion subject and the use of involved field RT instead of elective nodal radiation should be assessed by further prospective studies. Another role of FDG-PET in SCLC is the evaluation of response to treatment. It was found that assessment success of FDG-PET in patients who received chemotherapy and RT was high (80).

\section{Conclusion}

In conclusion, the most important contribution of FDGPET to the management of SCLC is in the accuracy of staging. Although RT use with the help of FDG-PET in this patient group is controversial, involved field radiation is an attention-grabbing method. FDG-PET treatment planning can change treatment strategy of SCLC patients with limited disease.

\section{Ethics}

Peer-review: Externally peer-reviewed.

\section{References}

1. Onishi $H$, Shirato $H$, Nagata $Y$, Hiraoka $M$, Fujino $M$, Gomi $K$, Niibe Y, Karasawa K, Hayakawa K, Takai Y, Kimura T, Takeda A, Ouchi A, Hareyama M, Kokubo M, Hara R, Itami J, Yamada K, Araki T. Hypofractionated stereotactic radiotherapy (HypoFXSRT) for stage I non-small cell lung cancer: updated results of 257 patients in a Japanese multi-institutional study. J Thorac Oncol 2007;2(Suppl 3):94-100.

2. Grills IS, Mangona VS, Welsh R, Chmielewski G, Mclnerney E, Martin S, Wloch J, Ye H, Kestin LL. Outcomes after stereotactic lung radiotherapy or wedge resection for stage I non-small-cell lung cancer. J Clin Oncol 2010;28:928-935.

3. Dogan N, Leybovich LB, Sethi A, Emami B. Improvement of dose distributions in abutment regions of intensity modulated radiation therapy and electron fields. Med Phys 2002;29:38-44.

4. Zelefsky MJ, Leibel SA, Kutcher GJ, Fuks Z. Three-dimensional conformal radiotherapy and dose escalation: where do we stand? Semin Radiat Oncol 1998;8:107-114.

5. Hanks GE, Hanlon AL, Schultheiss TE, Pinover WH, Movsas B, Epstein BE, Hunt MA. Dose escalation with 3D conformal treatment: five year outcomes, treatment optimization, and future directions. Int J Radiat Oncol Biol Phys 1998;41:501-510.

6. Van de Steene J, Linthout N, de Mey J, Vinh-Hung V, Claassens C, Noppen M, Bel A, Storme G. Definition of gross tumor volume in lung cancer: inter-observer variability. Radiother Oncol 2002;62:37-49.

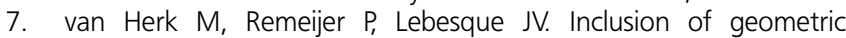
uncertainties in treatment plan evaluation. Int J Radiat Oncol Biol Phys 2002;52:1407-1422.

8. Lardinois D, Weder W, Hany TF, Kamel EM, Korom S, Seifert B, von Schulthess GK, Steinert HC. Staging of non- small-cell lung cancer with integrated positron-emission tomography and computed tomography. N Engl J Med 2003;348:2500-2507.

9. Lammering $G$, De Ruysscher D, van Baardwijk A, Baumert BG, Borger J, Lutgens L, van den Ende P, Ollers M, Lambin P. The use of FDG-PET to target tumors by radiotherapy. Strahlenther Onkol 2010;186:471-481.

10. Baum RP, Hellwig D, Mezzetti M. Position of nuclear medicine modalities in the diagnostic workup of cancer patients: lung cancer. Q J Nucl Med Mol Imaging 2004;48:119-142.

11. Weber WA, Wieder $\mathrm{H}$. Monitoring chemotherapy and radiotherapy of solid tumors. Eur J Nucl Med Mol Imaging 2006;33(Suppl 1):27-37.

12. Ling CC, Li XA. Over the next decade the success of radiation treatment planning will be judged by the immediate biological response of tumor cells rather than by surrogate measures such as dose maximization and uniformity. Med Phys 2005;32:21892192. 
13. Rubin P. Clinical Oncology, 8th ed. Philadelphia, Saunders 2001.

14. Kernstine KH, Mclaughlin KA, Menda Y, Rossi NP, Kahn DJ, Bushnell DL, Graham MM, Brown CK,Madsen MT. Can FDG-PET reduce the need for mediastinoscopy in potentially resectable non-small cell lung cancer? Ann Thorac Surg 2002;73:394-401.

15. Nestle U, Walter K, Schmidt S, Licht N, Nieder C, Motaref B, Hellwig D, Niewald M, Ukena D, Kirsch CM,Sybrecht GW, Schnabel K. 18F-deoxyglucose positron emission tomography (FDG-PET) for the planning of radiotherapy in lung cancer: high impact in patients with atelectasis. Int J Radiat Oncol Biol Phys 1999;44:593-597.

16. De Ruysscher $D$, Wanders $S$, Minken A, Lumens $A$, Schiffelers J, Stultiens C, Halders S, Boersma L,Baardwijk Av, Verschueren T, Hochstenbag M, Snoep G, Wouters B, Nijsten S, Bentzen SM, Kroonenburgh Mv, Ollers M, Lambin P. Effects of radiotherapy planning with a dedicated combined PET-CT-simulator of patients with non-small cell lung cancer on dose limiting normal tissues and radiation dose escalation: a planning study. Radiother Oncol 2005:77:5-10.

17. Li X, Zhang H, Xing L, Ma H, Xie P, Zhang L, Xu X, Yue J, Sun X, Hu $X$, Chen $M, X u$ W, Chen L, Yu J. Mediastinal lymph nodes staging by 18F-FDG PET/CT for early stage non-small cell lung cancer: a multi center study. Radiother Oncol 2012;102:246-250.

18. Hellwig D, Baum RP, Kirsch C. FDG-PET, PET/CT and conventional nuclear medicine procedures in the evaluation of lung cancer: a systematic review. Nuklearmedizin 2009;48:59-69.

19. Senan S, De Ruysscher D, Giraud P, Mirimanoff R, Budach V; Radiotherapy Group of European Organization for Research and Treatment of Cancer. Literature-based recommendations for treatment planning and execution in high-dose radiotherapy for lung cancer. Radiother Oncol 2004;71:139-146.

20. van Der Wel A, Nijsten S, Hochstenbag M, Lamers R, Boersma $L$, Wanders R, Lutgens L, Zimny M, Bentzen SM, Wouters B, Lambin P, De Ruysscher D. Increased therapeutic ratio by 18 FDG-PET-CT planning in patients with clinical CT stage N2/N3M0 non-small cell lung cancer: a modeling study. Int J Radiat Oncol Biol Phys 2005;61:649-655.

21. Hwangbo B, Kim SK, Lee HS, Lee HS, Kim MS, Lee JM, Kim HY, Lee GK, Nam BH, Zo Jl. Application of endobronchial ultrasoundguided transbronchial needle aspiration following integrated PET/ CT in mediastinal staging of potentially operable non-small cell lung cancer. Chest 2009;135:1280-1287.

22. Mac Manus MP, Wong K, Hicks RJ, Matthews JP, Wirth A, Ball DL. Early mortality after radical radiotherapy for non-small-cell lung cancer: comparison of PET-staged and conventionally staged cohorts treated at a large tertiary referral center. Int J Radiat Oncol Biol Phys 2002;52:351-361.

23. Mac Manus MP, Hicks RJ, Ball DL, Kalff V, Matthews JP, Salminen E, Khaw P, Wirth A, Rischin D, McKenzie A. F-18 fluorodeoxyglucose positron emission tomography staging in radical radiotherapy candidates with nonsmall cell lung carcinoma: powerful correlation with survival and high impact on treatment. Cancer 2001;92:886-895.

24. Kalff $V$, Hicks RJ, MacManus MP, Binns DS, McKenzie AF, Ware RE, Hogg A, Ball DL. Clinical impact of (18)F şuorodeoxyglucose positron emission tomography in patients with non-small-cell lung cancer: a prospective study. J Clin Oncol 2001;19:111-118.

25. Hicks RJ, Kalff $V$, MacManus MP, Ware RE, Hogg A, McKenzie AF, Matthews JP, Ball DL. (18)F-FDG PET provides high impact and powerful prognostic stratification in staging newly diagnosed nonsmall-cell lung cancer. J Nucl Med 2001;42:1596-1604.

26. Fox JL, Rengan R, O'Meara W, Yorke E, Erdi Y, Nehmeh S, Leibel SA, Rosenzweig KE. Does registration of PET and planning CT images decrease interobserver and intraobserver variation in delineating tumor volumes for non- small-cell lung cancer? Int J Radiat Oncol Biol Phys 2005;62:70-75.

27. Erdi YE, Rosenzweig K, Erdi AK, Macapinlac HA, Hu YC, Braban LE, Humm JL, Squire OD, Chui CS,Larson SM, Yorke ED. Radiotherapy treatment planning for patients with non-small cell lung cancer using positron emission tomography (PET). Radiother Oncol 2002;62:51-60.
28. Mah K, Caldwell CB, Ung YC, Danjoux CE, Balogh JM, Ganguli SN, Ehrlich LE, Tirona R. The impact of 18 FDG-PET on target and critical organs in CT-based treatment planning of patients with poorly defined non-small-cell lung carcinoma: a prospective study. Int J Radiat Oncol Biol Phys 2002:52:339-350.

29. Bradley J, Thorstad WL, Mutic S, Miller TR, Dehdashti F, Siegel BA, Bosch W, Bertrand RJ. Impact of FDG-PET on radiation therapy volume delineation in non-small-cell lung cancer. Int J Radiat Oncol Biol Phys 2004;59:78-86.

30. Ceresoli GL, Cattaneo GM, Castellone P, Rizzos G, Landoni C, Gregorc V, Calandrino R, Villa E, Messa C, Santoro A, Fazio F. Role of computed tomography and [18F] fluorodeoxyglucose positron emission tomography image fusion in conformal radiotherapy of non-small cell lung cancer: a comparison with standard techniques with and without elective nodal irradiation. Tumori 2007;93:8896.

31. Vanuytsel LJ, Vansteenkiste JF, Stroobants SG, De Leyn PR, De Wever W, Verbeken EK, Gatti GG, Huyskens DP, Kutcher GJ. The impact of 18F-fluoro-2-deoxy-D-glucose positron emission tomography (FDG-PET) lymph node staging on the radiation treatment volumes in patients with non-small cell lung cancer. Radiother Oncol 2000;55:317-324

32. Faria SL, Menard S, Devic S, Sirois C, Souhami L, Lisbona R, Freeman CR. Impact of FDG-PET/CT on radiotherapy volume delineation in non-small-cell lung cancer and correlation of imaging stage with pathologic findings. Int J Radiat Oncol Biol Phys 2008;70:1035-1038.

33. Yin LJ, Yu XB, Ren YG, Gu GH, Ding TG, Lu Z. Utilization of PET$\mathrm{CT}$ in target volume delineation for three-dimensional conformal radiotherapy in patients with non small cell lung cancer and atelectasis. Multidiscip Respir Med 2013;8:21.

34. Chi A, Nguyen NP. The utility of positron emission tomography in the treatment planning of image-guided radiotherapy for non-small cell lung cancer. Front oncol 2014;4:273.

35. Baş Ayata H, Güden M, Berberoğlu K, Küçük N, Ceylan C, Kiliç $A$ Akciğer tümörlü hastalarda hedef volümün belirlenmesinde PET-BT ve BT görüntü karşılaştıııması. Türk Onkoloji Derg 2010;25:1;1119.

36. Messa C, Di Muzio N, Picchio M, Gilardi MC, Bettinardi V, Fazio F PET/CT and radiotherapy. Q J Nucl Med Mol Imaging 2006;50:4-14.

37. Deniaud-Alexandre $E$, Touboul E, Lerouge D, Grahek D, Foulquier $J N$, Petegnief $Y$, Grès B, El Balaa $H$, Keraudy $K$, Kerrou $K$, Montravers F, Milleron B, Lebeau B, Talbot JN. Impact of computed tomography and 18F-deoxyglucose coincidence detection emission tomography image fusion for optimization of conformal radiotherapy in nonsmall- cell lung cancer. Int J Radiat Oncol Biol Phys 2005;63:1432-1441.

38. Doll $C$, Duncker-Rohr $V$, Rücker $G$, Mix $M$, MacManus $M, D e$ Ruysscher D, Vogel W, Eriksen JG, Oyen W, Grosu AL, Weber W, Nestle U. Influence of experience and qualification on PET-based target volume delineation. When there is no expert-ask your colleague. Strahlenther Onkol 2014;190:555-562.

39. Kubota R, Yamada S, Kubota K, Ishiwata K, Tamahashi N, Ido T. Intratumoral distribution of fluorine-18-fluorodeoxyglucose in vivo: high accumulation in macrophages and granulation tissues studied by microautoradiography. J Nucl Med 1992;33:1972-1980.

40. Duhaylongsod FG, Lowe VJ, Patz EF Jr, Vaughn AL, Coleman RE, Wolfe WG. Detection of primary and recurrent lung cancer by means of F-18 fluorodeoxyglucose positron emission tomography (FDGPET). J Thorac Cardiovasc Surg 1995;110:130-139.

41. Paulino AC, Johnstone PA. FDG-PET in radiotherapy treatment planning: Pandora's box? Int Jradiat Oncol Biol Phys 2004;59:4-5.

42. Yaremko B, Riauka T, Robinson D, Murray B, Alexander A, McEwan A, Roa W. Thresholding in PET images of static and moving targets. Phys Med Biol 2005;50:5969-5682.

43. Yaremko B, Riauka T, Robinson D, Murray B, McEwan A, Roa W. Threshold modification for tumour imaging in non-small-cell lung cancer using positron emission tomography. Nucl Med Commun 2005;26:433-440. 
44. Nestle $U$ Kremp $S$ Schaefer-Schuler A Sebastian-Welsch $C$ Hellwig D, Rübe C, Kirsch CM. Comparison of different methods for delineation of 18F-FDG PET-positive tissue for target volume definition in radiotherapy of patients with non-Small cell lung cancer. J Nucl Med 2005:46:1342-1348.

45. Zasadny KR, Kison PV, Francis IR, Wahl RL. FDG-PET Determination of metabolically active tumor volume and comparison with CT. Clin Positron Imaging 1998;1:123-129.

46. Lin $S$, Han B, Yu L, Shan D, Wang R, Ning X. Comparison of PET-CT images with the histological Picture of a resectable primary tumor for delineating GTV in non small cell lung cancer. Nucl Med Commun 2011:36:479-485.

47. van Baardwijk A, Bosmans G, Boersma L, Buijsen J, Wanders S, Hochstenbag M, van Suylen RJ, Dekker A, Dehing-Oberije C, Houben $R$, Bentzen SM, van Kroonenburgh M, Lambin $P$, De Ruysscher D. PET-CT-based auto-contouring in non-small-cell lung cancer correlates with pathology and reduces inter observer variability in the delineation of the primary tumor and involved nodal volumes. Int J Radiat Oncol Biol Phys 2007;68:771-778.

48. Geets X, Lee JA, Bol A, Lonneux M, Gregoire V. A gradient-based method for segmenting FDG-PET images: methodology and validation. Eur J Nucl Med Mol Imaging 2007;34:1427-1438.

49. Werner-Wasik $M$, Nelson $A D$, Choi $W$, Arai $Y$, Faulhaber PF, Kang P, Almeida FD, Xiao Y, Ohri N, Brockway KD, Piper JW, Nelson AS. What is the best way to contour lung tumors on PET scans? Multiobserver validation of a gradient-based method using a NSCLC digital PET phantom. Int J Radiat Oncol Biol Phys 2012;82:11641171.

50. Wanet $M$, Lee JA, Weynand $B$, De Bast $M$, Poncelet $A$, Lacroix $V$, Coche E, Grégoire V, Geets X. Gradient- based delineation of the primary GTV on FDG-PET in non-small cell lung cancer: a comparison with threshold-based approaches, CT and surgical specimens. Radiother Oncol 2011:98:117-125.

51. Cheebsumon $P$, Boellaard $R$, de Ruysscher $D$, van Elmpt $W$, van Baardwijk A, Yaqub M, Hoekstra OS, Comans EF, Lammertsma $A A$, van Velden $\mathrm{FH}$. Assessment of tumour size in PET/CT lung cancer studies: PET and CT based methods compared to pathology. EJNMMI Res 2012;2:56.

52. Yu HM, Liu YF, Hou M, Liu J, Li XN, Yu JM. Evaluation of gross tumor size using CT, 18F-FDG PET, integrated 18F-FDG PET/CT and pathological analysis in non-small cell lung cancer. Eur J Radiol 2009;72:104-113.

53. Yu J, Li X, Xing L, Mu D, Fu Z, Sun X, Sun X, Yang G, Zhang B, Sun $X$, Ling CC. Comparison of tumor volumes as determined by pathologic examination and FDG-PET/CT images of non-small cell lung cancer: a pilot study. Int J Radiat Oncol Biol Phys 2009;75:14681474.

54. Wu K, Ung YC, Hornby J, Freeman M, Hwang D, Tsao MS, Dahele M, Darling G, Maziak DE, Tirona R, Mah K, Wong CS. PET CT thresholds for radiotherapy target definition in non-small-cell lung cancer: how close are we to the pathologic findings? Int J Radiat Oncol Biol Phys 2010;77:699-706

55. Schaefer A, Kim YJ, Kremp S, Mai S, Fleckenstein J, Bohnenberger $H$, Schäfers HJ, Kuhnigk JM, Bohle RM, Rübe C, Kirsch CM, Grgic A. PET-based delineation of tumour volumes in lung cancer: comparison with pathological findings. Eur J Nucl Med Mol Imaging 2013;40:1233-1244.

56. Webb S. Motion effects in (intensity modulated) radiation therapy: a review. Phys Med Biol 2006;51:403-425.

57. Rengan $R$, Rosenzweig KE, Venkatraman $E$, Koutcher LA, Fox JL, Nayak R, Amols H, Yorke E, Jackson A, Ling CC, Leibel SA. Improved local control with higher doses of radiation in large-volume stage III non-small-cell lung cancer. Int J Radiat Oncol Biol Phys 2004;60:741747.

58. Nehmeh SA, Erdi YE, Pan T, Yorke E, Mageras GS, Rosenzweig KE, Schoder H, Mostafavi H, Squire O,Pevsner A, Larson SM, Humm JL. Quantitation of respiratory motion during 4D-PET/CT acquisition. Med Phys 2004;31:1333-1338.
59. Lamb JM, Robinson C, Bradley J, Laforest R, Dehdashti F, White BM, Wuenschel S, Low DA. Generating lung tumor internal target volumes from 4D-PET maximum intensity projections. Med Phys 2011;38:5732-5737.

60. Jeremic B. Incidental irradiation of nodal regions at risk during limited-field radiotherapy (RT) in dose-escalation studies in nonsmall cell lung cancer (NSCLC). Enough to convert no-elective into elective nodal irradiation (ENI)? Radiother Oncol 2004;71:123-125.

61. Liao $\mathrm{CT}$, Chen JH, Liang JA, Yeh JJ, Kao CH. Meta-analysis study of lymph node staging by 18F-FDGPET/CT scan in non-small cell lung cancer. Comparison of TB and non-TB endemic regions. Eur J Radiol 2012:81:3518-3523.

62. Mac Manus MP, Hicks RJ, Matthews JP, Wirth A, Rischin D, Ball DL. Metabolic (FDG-PET) response after radical radiotherapy/ chemoradiotherapy for non-small cell lung cancer correlates with pattern of failure. Lung Cancer 2005;49:95-108.

63. Lopez Guerra JL, Gladish G, Komaki R, Gomez D, Zhuang Y, Liao Z. Large decreases in standardized uptake values after definitive radiation are associated with better survival of patients with locally advanced non-small cell lung cancer. J Nucl Med 2012;53:225233.

64. Erasmus JJ, Patz Jr E. Positron emission tomography imaging in the thorax. Clin Chest Med 1999;20;715-724.

65. Velasquez ER, Aerts HJ, Oberije C, De Ruysscher D, Lampin P. Prediction of residual metabolic activity after treatment in NSCLC patients. Acta Oncol 2010;49:1033-1049.

66. Fleckenstein J, Hellwig D, Kremp S, Grgic A, Gröschel A, Kirsch CM, Nestle U, Rübe C. F-18- FDG-PET confined radiotherapy of locally advanced NSCLC with concomitant chemotherapy:results of the PETPLAN pilot trial. Int J Radiat Oncol Biol Phys 2011;81:283-289.

67. van Baardwijk $A$, Reymen $B$, Wanders $S$, Borger J, Ollers $M$, Dingemans AM, Bootsma G, Geraedts W, Pitz C, Lunde R, Peters

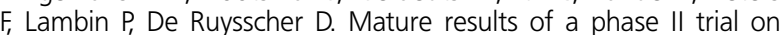
individualised accelerated radiotherapy based on normal tissue constraints in concurrent chemoradiation for stage III non-small cell lung cancer. Eur J Cancer 2012;48:2339-2346.

68. Chi A, Nguyen NP, Welsh JS, Tse W, Monga M, Oduntan O, Almubarak M, Rogers J, Remick SC, Gius D. Strategies of dose escalation in the treatment of locally advanced non-smallcell lung cancer: image guidance and beyond. Front Oncol 2014;4:156.

69. Aupérin $A$, Le Péchoux $C$, Rolland $E$, Curran WJ, Furuse $K$, Fournel $P$, Belderbos J, Clamon G, Ulutin HC, Paulus R, Yamanaka T, Bozonnat MC, Uitterhoeve A, Wang X, Stewart L, Arriagada R, Burdett $S$, Pignon JP. Meta-analysis of concomitant versus sequential radiochemotherapy in locally advanced non-small-cell lung cancer. J Clin Oncol 2010;28:2181-2190.

70. Shirai K, Nakagawa A, Abe T, Kawahara M, Saitoh J, Ohno T, Nakano T. Use of FDG-PET in radiation treatment planning for thoracic cancers. Int J Mol Imaging 2012;2012:609545.

71. Fischer BM, Mortensen J, Langer SW, Loft A, Berthelsen AK, Petersen BI, Daugaard G, Lassen U, Hansen HH. A prospective study of PET/CT in initial staging of small-cell lung cancer: comparison with $\mathrm{CT}$, bone scintigraphy and bone marrow analysis. Ann Oncol 2007;18:338345.

72. Bradley JD, Dehdashti F, Mintun MA, Govindan R, Trinkaus K, Siegel BA. Positron emission tomography in limited-stage small-cell lung cancer: a prospective study. J Clin Oncol 2004;22:3248-3254.

73. Niho S, Fujii H, Murakami K, Nagase S, Yoh K, Goto K, Ohmatsu H, Kubota K, Sekiguchi R, Nawano S, Saijo N, Nishiwaki Y. Detection of unsuspected distant metastases and/or regional nodes by FDG-PET in LD-SCLC scan in apparent limited-disease small-cell lung cancer. Lung Cancer 2007;57:328-333.

74. Arslan N, Tuncel M, Kuzhan O, Alagoz E, Budakoglu B, Ozet A, Ozguven MA. Evaluation of outcome prediction and disease extension by quantitative 2-deoxy-2-[18F] fluoro-D-glucose with positron emission tomography in patients with small cell lung cancer. Ann Nucl Med 2011;25:406-413. 
75. Baas P, Belderbos JS, Senan S, Kwa HB, van Bochove A, van Tinteren $H$, Burgers JA, van Meerbeeck JP. Concurrent chemotherapy (carboplatin, paclitaxel, etoposide) and involved-field radiotherapy in limited stage small cell lung cancer: a Dutch multicenter phase II study. Br J Cancer 2006;94:625-630.

76. De Ruysscher D, Bremer RH, Koppe F, Wanders S, van Haren E, Hochstenbag M, Geeraedts W, Pitz C, Simons J, ten Velde G, Dohmen J, Snoep G, Boersma L, Verschueren T, van Baardwijk A, Dehing C, Pijls $M$, Minken A, Lambin P. Omission of elective node irradiation on basis of CT-scans in patients with limited disease small cell lung cancer: a phase II trial. Radiother Oncol 2006;80:307-312.

77. Videtic GM, Belderbos JS, Spring Kong FM, Kepka L, Martel MK, Jeremic B. Report from the International Atomic Energy Agency (IAEA) consultants' meeting on elective nodal irradiation in lung cancer: smallcell lung cancer (SCLC). Int J Radiat Oncol Biol Phys 2008;72:327-334.
78. van Loon J De Ruysscher D, Wanders R, Boersma L, Simons J, Oellers $M$, Dingemans AM, Hochstenbag M, Bootsma G, Geraedts W, Pitz C, Teule J, Rhami A, Thimister W, Snoep G, Dehing-Oberije C, Lambin P. Selective nodal irradiation on basis of (18) FDG-PET scans in limited disease small-cell lung cancer: a prospective study. Int J Radiat Oncol Biol Phys 2010;77:329-336.

79. Shirvani SM, Komaki R, Heymach JV, Fossella FV, Chang JY. Positron emission tomography/computed tomography-guided intensitymodulated radiotherapy for limited stage small-cell lung cancer. Int J Radiat Oncol Biol Phys 2012;82:91-97.

80. van Loon J, Offermann $C$, Ollers $M$, van Elmpt $W$, Vegt $E$, Rahmy A, Dingemans AM, Lambin P, De Ruysscher D. Early CT and FDGmetabolic tumour volume changes show a significant correlation with survival in stage 1-III small cell lung cancer: a hypothesis generating study. Radiother Oncol 2011;99:172-175. 